\title{
Somatic growth rates of immature green turtles Chelonia mydas inhabiting the foraging ground Akumal Bay in the Mexican Caribbean Sea
}

Vanessa Labrada-Martagón ${ }^{1,4}$, Fernando A. Muñoz Tenería ${ }^{1 *}$, Roberto Herrera-Pavón ${ }^{2}$, Ana Negrete-Philippe ${ }^{3}$

${ }^{1}$ Facultad de Agronomía y Veterinaria-UASLP, Carretera Matehuala-SLP Km 14.5, Soledad de Graciano Sánchez, San Luis Potosí, México, vlabrada@gmail.com

${ }^{2}$ El Colegio de la Frontera Sur, Av. del Centenario Km. 5.5, Chetumal, Quintana Roo, México,rherrera@ecosur.mx

3Parque Xcaret, Carretera Chetumal-Pto. Juarez km 262, Playa del Carmen, Quintana Roo, México, anegrete@experienciasxcaret.com.mx

*Corresponding author

Facultad de Agronomía y Veterinaria, Universidad Autónoma de San Luis Potosí, Carretera San Luis Potosí - Matehuala km. 14.5

Soledad de Graciano Sánchez, S.L.P., C.P. 78321, México

Email: fernando.munoz@uaslp.mx

Phone: +52(444) 852-40-56 al 59 ext. 1136

${ }^{4}$ Present address: Facultad de Ciencias, UASLP, Lateral Av. Salvador Nava s/n. Zona Universitaria, CP 78290, San Luis Potosí, México. 


\section{Abstract}

Growth dynamics helps to elucidate demographic aspects, such as age at specific size and size at maturity or first reproduction, which are important for sea turtle management. The Mexican Caribbean Sea is an important feeding ground for green turtles, but demographic data for the turtles are lacking. Size-based growth rates of immature green turtles inhabiting a foraging ground at Akumal Bay (20 24' 0 ' $\mathrm{N}$ and $87^{\circ} 19^{\prime} 16^{\prime}$ ' W) were obtained by using a mixed longitudinal sampling design from historic mark-recapture data (20042014). Curved carapace length (CCL) of immature turtles at first capture ranged from 27.8$81.0 \mathrm{~cm}$ and minimum size at recruitment was $27.8 \mathrm{~cm}$ CCL. Recapture intervals ranged from 1-49 months, $72 \%$ of the recaptures $(n=172)$ occurred in less than a year and $90 \%$ before 1.5 years. A monotonic size-specific growth function displays the maximum growth

rate $\left(6.25 \mathrm{~cm} \mathrm{yr}^{-1}\right)$ at about $46-48 \mathrm{~cm} \mathrm{CCL}$ before starts declining steadily at $>60 \mathrm{~cm}$ CCL. Mean size presented a non-linear relationship with growth rates and year of capture had a negative linear effect over growth; the lowest annual mean growth rates were registered during 2009 and 2012. Based on GAM predictions an immature sea turtle recruited to the feeding ground (28 cm CCL) would require between 13-14 years to reach the average nesting size, supporting field observations. A negative linear relationship between annual mean growth rate and the relative estimated sea turtle abundance $(p=0.001)$ suggests a density-dependent effect. The quantitative information presented will help understand life history patterns and provide a baseline to assess future dynamics of this green turtle population.

Keywords: Caribbean, demography, somatic growth, generalized linear model, green turtle, Chelonia mydas. 


\section{Introduction}

Growth dynamics is one of the keys aspects of life history. In turtle management, it is used to elucidate age at specific size, size at maturity, age at first reproduction and recruitment of specific sea turtle populations. These priority parameters are required to assess demographic changes in natural populations in response to endogenous regulatory factors (e.g. nutritional, physiological, behavioural) and environmental influences or anthropogenic pressures. Thus, understanding demographic parameters of threatened species, such as sea turtles, allows the formulation of the appropriate conservation status, policies and sustainable management strategies (Balazs, 1995; Bjorndal, 1999; Eberhardt, 1985; Hamann et al., 2010; Heppell et al., 2003; Seminoff et al., 2002b). When working with free-ranging sea turtles, it is difficult to obtain biological data from long time series studies and tagging monitoring programs because of the effort required, the long life span of the animals, inaccessibility of some habitats and their oceanic life cycle (Bjorndal, 1999; Heppell et al., 2003). Demographic and behavioural data are available mostly for females on nesting beaches and for specific populations of sea turtles that are routinely and intensively monitored [e.g. in Hawaii, Australia, and the Mediterranean (Balazs, 1995; Balazs and Chaloupka, 2006; Casale et al., 2011; Chaloupka et al., 2004).

Natural variability of somatic growth rates is attributable to age-specific, cohort-specific and interannual factors (Chaloupka and Musick, 1997). Differences in growth rates between green turtle populations have been explained by environmental stochasticity (El Niño event, cyclone, flood) and differences in habitat quality, such as composition and quality of food (Balazs and Chaloupka, 2004b; Chaloupka et al., 2004; Velez-Zuazo et al., 2014). Gender, diet and sea turtle density are additional intrinsic factors defining sea turtle 
growth (Bjorndal et al., 2000; Chaloupka et al., 2004; Lopez-Castro et al., 2010). Immature green turtles (Chelonia mydas) are estimated to spend decades inhabiting feeding grounds until they grow and reach sexual maturity (Bjorndal et al., 2000; Seminoff et al., 2002b). This makes this age class particularly vulnerable to density-dependent factors, such as changes in food supply, oceanographic and local habitat conditions, anthropogenic perturbations, fisheries bycatch and illegal capture (Bjorndal et al., 2000; Koch et al., 2006; Labrada-Martagón et al., 2011; Labrada-Martagón et al., 2013; Mancini and Koch, 2009; Peckham et al., 2008).

The green turtle is a circumglobal species nesting and foraging in tropical and subtropical waters (Marquez, 1990; Pritchard, 1997). In the Western Atlantic (Caribbean Sea), some of the most important nesting beaches include Tortuguero in Costa Rica and Aves Island in Venezuela (Pritchard, 1997). The coast of Yucatán and Quintana Roo in the Mexican Caribbean also provides at least 14 nesting beaches, $65 \%$ of which are protected, along with favorable feeding habitats for immature green turtles (CONANP, 2011; Zurita, 2015). In this region, conservation efforts have focused on nesting beach protection and headstarting programs. One of the main concerns for sea turtle conservation and preservation of natural habitats in the coastal area of Quintana Roo is urban development and associated land use (Thomassiny and Chan, 2011). Over the last decade, activities such as increased tourism development around important feeding grounds. e.g. Akumal Bay (Maldonado et al., 2006; Ruiz-Alonso, 2008), and swimming with sea turtles (Slater, 2014) have been negatively affecting important nesting and feeding areas in Mexico. Our goal was to estimate growth rates of immature green turtles in Akumal Bay monitored over a period of ten years and to asses which factors influence these rates (e.g. relative sea turtle abundance and size). 


\section{Material and methods}

2.1. Study area. — Field work was conducted from 2004 to 2014 in Akumal Bay (20²4' 0" $\mathrm{N}$ and $87^{\circ} 19^{\prime} 16^{\prime} \mathrm{W}$ ), which is part of the tourism corridor Cancún-Tulúm in Quintana Roo, Mexico (Barrera-Escorcia and Namihira-Santillán, 2004). Akumal bay has a 2 km long beach, which is protected from waves by a barrier reef approximately $300 \mathrm{~m}$ offshore. Year-round air temperature ranges from $8-36.6^{\circ} \mathrm{C}$, annual mean air temperature is $26^{\circ} \mathrm{C}$ with summer rains and sea surface temperature can reach $25.5^{\circ} \mathrm{C}$ (Molina and Van Tussenbroek, 2014; Ruiz-Alonso, 2008; Zurita, 2015). Seagrass meadows serve as foraging grounds for immature green, loggerhead and hawksbill turtles and cover a total of 4 to 5 ha, ranging from a depth of 1.5 to 3 meters; they are characterised by perennial Thalassia testudinum and associated species Syringodium filiforme, Halodule and rhizophytic algae. (Barrera-Escorcia and Namihira-Santillán, 2004; CEA, 2015; Molina and Van Tussenbroek, 2014; Ruiz-Alonso, 2008; Slater, 2014; Van Tussenbroek, 1995). Akumal is also a nesting area for green and loggerhead turtles (Caretta caretta). Tourism has increased in the last decade (Thomassiny and Chan, 2011), and a management program to regulate the activities and the number of boats and visitors to the bay was proposed in 2006 (CEA, 2015; Maldonado et al., 2006).

2.2. Sea turtle capture and growth data. - Turtles were captured throughout the year by hand for swimmers snorkelled when they were feeding or resting quietly on the bottom. Curved carapace length (CCL) was measured from the anterior point at midline (nuchal scute) to the posterior tip of the supracaudals, and curve carapace width $(\mathrm{CCW})$ was 
measured at the widest point (Bolten, 1999) to the nearest $0.1 \mathrm{~cm}$ with a measuring tape. All turtles were marked with Monel tags (National Band and Tag Company, NBTC, Newport, Kentucky, USA) attached in the axillary position in one of the anterior flippers of each sea turtle (Balazs, 1999; Limpus, 1992). A combination of two letters and three numbers was used as code.

Animals lacking secondary sexual characteristics were classified as immature sea turtles; this classification was also based on their size by using the lower limit of the range size of nesting females reported in Quintana Roo [86 - $124 \mathrm{~cm}$ CCL, (Zurita et al., 1993)]. Sex was unknown given the absence of sexual dimorphism in immature sea turtles (LabradaMartagón et al., 2014). Capture per unit effort (CPUE) was calculated as the number of sea turtles captured per year divided by the total effort units (hours of snorkelling) (LabradaMartagón et al., 2010) and used as an indicator of relative sea turtle abundance (Bjorndal et al., 2000).

Historic mark-recapture data of green turtles (from 2004 to 2014) consisted of year of first capture, time interval in months since first capture or previous recapture, size (CCL) at first capture and at subsequent recaptures and growth rate described in terms of CCL. Size-based growth rates were obtained by using a mixed longitudinal sampling design (sampling with partial replacement) (Chaloupka and Musick, 1997). Age of sea turtles was unknown for $94 \%$ of the animals captured; the $6 \%$ of sea turtles with growth increments were part of a headstarting program from $1998(n=4), 2000(n=1)$ and $2004(n=5)$ and therefore of known age (Zurita, 2015). Thereby, the effects of year and cohort factors were confounded in this study (Chaloupka and Musick, 1997). Absolute growth rates were calculated as previously described using the equation 
$C C L_{\text {final }}-C C L_{\text {initial }} /$ recapture interval in years (Seminoff et al., 2002b). Recapture intervals greater than 11 months, including repeated measures, were considered $(n=86)$ when estimating growth by mean size classes and annual growth rates in order to avoid possible seasonal effects and to minimise error estimations (Chaloupka and Limpus, 1997; Chaloupka and Musick, 1997; Limpus and Chaloupka, 1997; Seminoff et al., 2002b). The $12.8 \%(n=11)$ of the total growth increments considered in the analyses came from headstarted sea turtles. The variable "year" was assigned for each growth record considering the beginning of the recapture period (year of first capture) in order to evaluate the relationship between the relative abundance in the feeding ground in a year with growth performance of the animals. Including the calendar year in the analyses accounted for variability in growth, given environmental or cohort (genetic) factors as resultant of the implicit time-dependent sampling design (Bjorndal et al., 2000; Chaloupka and Limpus, 1997). Multiple growth measurements per individual and negative growth measurements were included in the analyses (Chaloupka and Musick, 1997). Absolute growth rates of sea turtles with recapture intervals larger than 24 months (2-7 years) were assumed to be from resident turtles. Mean growth rates were estimated by mean size classes in order to account for size-specific growth rate (Chaloupka and Musick, 1997). Mean CCL was defined as the arithmetic mean of size at first capture and size at recapture (Bjorndal et al., 2000).

\subsection{Statistical analyses. - Descriptive statistical values and distribution frequencies by} size and recapture intervals were plotted in histograms. Normality (Kolmogorov-Smirnov test and Shapiro-Wilk test) and homogeneity of variance (Barlett's test) assumptions were assessed. Annual differences in recapture interval, CCL and growth rates, grouped by year of first capture, were evaluated using parametric (ANOVA) or non-parametric analyses 
(Kruskal Wallis test), depending on whether data fit assumptions of normality and equal variance. Tukey's test was used as multiple comparison analysis when significant differences were found (ANOVA). Linear regression analyses were used to evaluate the relationship between the frequency of recapture with annual CPUE and between annual mean growth rate and relative sea turtle abundance. All results were considered significant with $\alpha=0.05$. Univariate statistical analyses were run in Statistica v.8 (StatSoft, 2007).

\subsection{Non-linear modelling procedure. - Generalized additive model (GAM) analysis was} used in this study to evaluate the non-linear relationship between growth rate of sea turtles (response variable) and the explanatory variables means size, recapture interval and year as previously described by Chaloupka and Limpus (1997); Limpus and Chaloupka (1997). GAM replaces the linear form of the regression model by an additive smooth function to fit the data, allowing for non-linear relationships between the response variable and multiple explanatory variables (Hastie and Tibshirani, 1986). The response variable is modelled as a sum of smooth functions of the covariates (Wood, 2006). Models were fitted by using an identity link, cubic smoothing splines in all covariates (Wood, 2006; Zuur et al., 2009) to minimise small sample size and outlier effects when estimating the non-linear form (Chaloupka and Limpus, 1997) and a quasi-likelihood error function as the smoothing parameter estimation which accounts for the potential correlated error du to the mixed longitudinal nature of data (McCullagh and Nelder, 1989). Spearman correlation coefficients were used to evaluate correlation between covariates "mean size", "year" and "recapture interval" previous to multivariate analyses. Given the low correlation found between covariates "year" and "recapture interval" $(r=-0.34, p=0.001)$, significant changes in the associated degrees of freedom (amount of smoothing) if one term was omitted were 
not found that suggested collinearity effects during modelling selection (Katz, 2006; Zuur et al., 2009). Thus, different models were test, including a model with the covariate "year" as categorical variable, and selection of growth descriptive models were based on the significance of the contribution of each variable in the model $(p<0.05)$, by comparing the Akaike Information Criteria (AIC) and by hypothesis testing procedure ( $F$-test) (Wood, 2006; Zuur et al., 2009). Plot of residuals was used as a diagnostic method to assess normality, homoscedasticity and model fit (Zuur et al., 2009).

Mean nesting size of females (106.6 cm CCL) observed in Quintana Roo (Zurita et al., 1993) was used to estimate the number of years that a sea turtle requires to spend in Akumal by using the growth rates predictions derived from the multivariate model. Sizespecific estimations was obtained for the range between 27 (minimum recruitment size) to $65 \mathrm{~cm}$ CCL, by holding the other two covariates constant. We chose year 2007 or 2009 , periods with the highest and the lowest growth rates respectively (Table 4), and the average recapture interval (18.4 months) as constants. Size range used was chosen to avoid wide confidence intervals observed at a size $>65 \mathrm{~cm}$ CCL. All modelling was performed using R package “mgcv” (Wood, 2016) in R v.3.1.3 (R Core Team, 2015).

\section{Results}

3.1. Population structure. - A total of 166 green turtles were captured during the monitoring period of ten years. Green turtles at first capture ranged from $27.8-81.0 \mathrm{~cm}$ CCL (mean \pm standard deviation, $56.17 \pm 11.31 \mathrm{~cm} \mathrm{CCL}$, Fig. 1). Greatest annual CPUE values were found in 2008 and 2012-2014 (Table 1). 
3.2. Capture - recapture data. - Rate of tag loss was $0 \%$, and tags were replaced in $4 \%$ $(n=7)$ of the individuals recaptured when tag started to be imbedded with tissue or when one of both tags was found. Signs of corrosion in Monel tags (nickel-copper alloy) were not found, neither signs of infections or lasting lesions at the tag site were observed which could impair or affect the animal's behaviour.

Seventy-six (45.85\%) of the 166 green turtles were recaptured at least once (Table 1). The $65 \%$ of growth data originated from recaptured individuals and were thus repeated measurements. A total of 33 sea turtles were recaptured once $(19.9 \%), 7.8 \%(n=13)$ were recaptured twice, $10.2 \%(n=17)$ were recaptured tree times, $4.2 \%(n=7)$ were recaptured four times, $1.8 \%(n=3)$ were recaptured five times and $0.6 \%(n=1)$ were recaptured six, eight or ten times.

Annual frequency of recaptures (\%) and CPUE are presented in Table 1. Rates of recaptures varied between years; however, we found no correlation between annual relative frequency of recaptures and annual CPUE $(r=-0.28, p=0.47)$. Recapture interval related to the time of first capture ranged from 1 month to 6.6 years; the range of the recapture interval was 1-49 months when considering all previous recaptures (repeated measures). Seventy-two percent (124/172) of the recaptures occurred in less than a year and $90 \%$ before 1.5 years (Fig. 2a). Recapture interval was the longest for animals captured in 2006 (4.1 years) and shortest for 2007 and 2011 (1.3 and 1.4 years, respectively) (Fig. 2b). Recapture intervals of sea turtles from 2013 and 2014 where shorter than those observed in $2004\left(F_{(9,66)}=4.31, p<0.001\right)$; sea turtles captured in 2014 were smaller (CCL) at the time of the last recapture relative to individuals of $2004\left(F_{(9,66)}=2.47, p=0.02\right)$. Mean CCL at time 
of last recapture, excluding those from 2014, was $66.4 \pm 9.6 \mathrm{~cm}(n=70)$, with a range of $42.5-82.8 \mathrm{~cm}$ (Fig. 1).

3.3. Growth. - Growth rates ranged between 0.38 and $14.03 \mathrm{~cm} \mathrm{CCL} \mathrm{yr}^{-1}$ when all growth increments are considered. Absolute mean growth rate of sea turtles with recapture intervals greater than 24 months was $5.83 \pm 0.61 \mathrm{~cm} \mathrm{CCL} \mathrm{yr}^{-1}$ (Table 2). The $64 \%$ of growth data was estimated from sea turtles with a mean size ranging from 53 to $67 \mathrm{~cm} \mathrm{CCL}$ (Table 3). A significant negative relationship between annual mean growth rate and estimated sea turtle abundance was found $\left(r^{2}=0.78, r=-0.88, p=0.001\right.$, Fig. 3a).

Multivariate model selected to explain growth rates of green turtles in Akumal (Table 4) comprised the covariates mean size, recapture interval and year as covariates $\left(r^{2}=0.19\right.$, deviance explained $=22.7 \%)$. The explanatory variable mean size (CCL) presented a significant non-linear relationship with growth rates $(p<0.03)$ and year presented a linear negative effect over growth $(p=0.05)$ (Fig. 4). There was no significant effect of the recapture interval $(p=0.08)$ that contributes in explaining growth rate (Table 4$)$. The sizespecific growth rate function was monotonic; the maximum growth rate $\left(6.25 \mathrm{~cm} \mathrm{CCL} \mathrm{yr}^{-1}\right)$ occurred at around 46 to $48 \mathrm{~cm} \mathrm{CCL}$, then the function starts declining steadily at a size $>60 \mathrm{~cm}$ CCL (Fig 5). When year was included as factor (Table 4) GAM identified particular years in which green turtles presented slower growth rates that was not accounted by an univariate analysis (Kruskall-Wallis, $H_{(8,86)}=13.68, p=0.09$ ). During 2008 growth rates were 2.45 units lower $(p=0.06)$ than other years, in 2009 were 3.17 units lower ( $p=0.02)$ and 2.43 units lower $(p=0.04)$ during 2012. According to GAM predictions (Fig. 5a), an immature sea turtle recruited to Akumal at the minimum size observed in this study 
(28 cm CCL) would require between 13 and 14 years in order to reach the mean nesting size of nesting females in Quintana Roo (106.6 cm CCL) (Fig 5b).

\section{Discussion}

Life history traits, such as slow growth and delayed sexual maturity, in long-lived organisms such as sea turtles have large impacts on fitness (e.g. higher number of eggs through longer growth) and juvenile survival (Congdon et al., 1993; Stearns, 1992). These traits, along with reproduction characteristics, determine long-term population trends and constrain the ability of natural populations to respond to environmental change (e.g. global warming) and increased human impacts (Congdon et al., 1993; Heppell et al., 2003).

The mark-recapture program in Akumal was very successful in terms of tag retention $(0 \%$ of tags lost) and in proportion of individuals recaptured (close to $50 \%$ of the sea turtles marked) in a short time frame ( $90 \%$ of recaptures in 18 months). Annual recapture rates of this study were between 25 and $85 \%$ contrasting with reports about East Pacific green turtles in Baja California Peninsula (9-33\% annual recapture rates) (Koch et al., 2007). A tag retention rate similar to this study has been reported before in Quintana Roo in a study over a period of five years; 709 nesting female green turtles were tagged and only $5 \%$ of the individuals presented scars of missing tags (Zurita, 2015). Multiple factors are involved in tag retention, such as characteristics of the marine environment (rates of tag loss are lower in feeding grounds), size class tagged, tagging position, the experience of the person tagging and conditions of the tagging gear (Balazs, 1999; Limpus, 1992). 
Somatic growth for mark-recaptured animals can be described in terms of curve or straight carapace length in sea turtles (Chaloupka and Musick, 1997). Using curve measures could lead to greater measurement errors, given the variability in positioning the flexible measuring tape along the carapace or the presence of epibionts on the shell surface (Balazs, 1995; Bolten, 1999). In Akumal, the presence of epibionts in immature individuals was uncommon. The CCL notch to tip was the only measurement considered during the monitoring program and taken only by three members of the research team during the ten years of the monitoring program in order to increase measurement precision (Bolten, 1999).

Inshore feeding grounds are important areas not just for protection and growth of immatures green turtles (Chaloupka et al., 2004; Lopez-Castro et al., 2010; LopezMendilaharsu et al., 2005; Seminoff et al., 2002a), but also as foraging and over-wintering sites for non-breeding adult turtles that spend long periods feeding until they reach the nutritional threshold required for migration, breeding and nesting (Broderick et al., 2007; Godley et al., 2002; Hamann et al., 2002a; Hamann et al., 2002b; Méndez et al., 2013). Data on somatic growth was obtained for immature sea turtles which had already recruited to the feeding ground in Akumal; between four and 33 new individuals were included each year to the mark-recapture program. When a mixed longitudinal sampling design is used, the growth study is based on different groups of individuals followed over different periods. Some individuals were lost and new ones were included in the course of the study (sampling with partial replacement) (Chaloupka and Musick, 1997; Goldstein, 1968). In Akumal, the minimum size registered over ten years of monitoring was $28 \mathrm{~cm} \mathrm{CCL}$. This measure is within the range $(20-30 \mathrm{~cm}$ carapace length) reported for immature green turtles 
recruiting to neritic habitats in the Atlantic (Lahanas et al., 1998; Mendonça and Ehrhart, 1982) and could be considered the minimum recruitment size in Akumal.

Data about recapture periods provide information about time of residency of sea turtles in the feeding ground and their annual changes. Sea turtles from Akumal were recaptured repeatedly from one to 79 months after first capture, suggesting residency of green turtles in the coast of Quintana Roo for more than six years. Individuals first captured during 2006 and 2009 were seen for the longest periods, 4.1 and 3.4 years, respectively. In the Bahamas, recapture intervals ranged from 0.9 to 6 years, coinciding with our observations (Bjorndal et al., 2000). Other authors have suggested that in Florida, juvenile green turtles present foraging site fidelity, and some of them became residents of estuaries and occupy stable home ranges along nearshore all year round (Makowski et al., 2006; Mendonça and Ehrhart, 1982). In Caribbean waters (U.S. Virgin Islands, Bahamas and Peninsula of Yucatán), green turtles have been seen moving between foraging (immatures) or home ranges (post-nester females), covering an average distance between five to seven kilometres inside their home range in Yucatán (Lahanas et al., 1998; Méndez et al., 2013; Williams, 1988). Size-dependent shifts in microhabitat preference (Ballorain et al., 2010; LópezMendilaharsu et al., 2005) or local neritic migrations from and to Akumal during the juvenile and sub-adult developmental phases cannot be discarded in the green turtle population inhabiting Quintana Roo.

Mean growth rates of green turtles in Akumal $\left(5.7 \pm 2.3 \mathrm{~cm} \mathrm{yr}^{-1}\right)$ were higher than those reported (recapture interval > 11 months) for immature Caribbean green turtles from the Bahamas (4.2 $\left.\mathrm{cm} \mathrm{yr}^{-1}\right)$ (Bjorndal et al., 2000), U.S. Virgin Islands (4.8 $\left.\mathrm{cm} \mathrm{yr}^{-1}\right)$ (Boulon and Frazer, 1990) and Danish West Indies (4.7 $\mathrm{cm} \mathrm{yr}^{-1}$ ) (Schmidt, 1916). Major discrepancies 
are found when comparing growth rates between species or ocean basins, the former may be related to inter-basin differences in primary productivity and environmental stochasticity, resulting in differential resource availability (Wallace et al., 2006a; Wallace et al., 2006b). In Akumal, average growth rate of green turtles was higher than estimations observed in juvenile loggerhead sea turtles (Caretta caretta) from the Western North Atlantic (North Carolina) (Braun-McNeill et al., 2008) and the Southern Great Barrier Reef green turtle population (Chaloupka et al., 2004; Limpus and Walter, 1980) and at least two times higher than growth rates of East Pacific green turtle populations (mean range 0.14$2.83 \mathrm{~cm} \mathrm{yr}^{-1}$ ) at the occidental coast of Baja California Sur, Gulf of California, Galápagos Islands and in Peru (Balazs, 1995; Green, 1993; Koch et al., 2007; Lopez-Castro et al., 2010; Seminoff et al., 2002b; Velez-Zuazo et al., 2014). Green turtles in Atlantic and Caribbean waters grow faster than turtles in the Pacific (Bjorndal and Bolten, 1988; Green, 1993), and our results support this assumption. In Mexican green turtle stocks, the East Pacific population, locally known as "black turtle", has the slowest growth rates when compared with the "white" morphotype from Quintana Roo (this study). A similar pattern has been observed between both morphotypes of Chelonia mydas in Galapagos Islands, with green turtles having higher grow rates than black turtles in the same area (Green, 1993). Differences in growth rates between green turtle populations and within the same genetic stocks have been explained by environmental factors, such as habitat quality (composition and quality of food), food dynamics, environmental stochasticity (El Niño event, cyclone, flood), season (reduced sea turtle activity during winter), sea surface water temperature and differences in sampling protocols or in habitat management category (Balazs and Chaloupka, 2004a; Chaloupka et al., 2004; Koch et al., 2007; Lopez-Castro et al., 2010; Seminoff et al., 2002b; Velez-Zuazo et al., 2014). Type of measurement (curve or 
straight) and size ranges (slow/faster growth) differ somewhat between our study and those of others, possibly, methodological aspects of data analyses, such as inclusion or exclusion of data (zero or negative values) to estimate growth rates, also varied. In summary, conclusions should be taken with caution when growth rates of different sea turtle populations are compared (Bjorndal and Bolten, 1988; Chaloupka and Musick, 1997).

Annual growth rates of sea turtles within a study period of ten years in Akumal were negatively correlated with annual relative abundance, suggesting a density-dependent effect on growth (Beverton and Holt, 1957). CPUE used in this study is considered a reliable population index of relative abundance (Bjorndal et al., 2000; Haddon, 2001). The results of this linear regression analysis are not conclusive and have to be taken with caution considering the heterogeneity of growth data across years, the total units of effort ( $4-14$ hours), and small number of sea turtles capture in particular years. Although, significant lower growth rates, denoted by the parametric coefficients estimated by the multivariate model fitted (Zuur et al., 2009), was observed in years when the highest relative abundance of sea turtles (2009 and 2012), thus supporting the univariate results (the negative relationship between growth and sea turtle abundance) and our density-dependence hypothesis in the bay. Density-dependent effects on growth rates and body condition have been reported before in the Bahamas and the recovering Hawaiian stock in periods with greater abundance of green turtles (Balazs and Chaloupka, 2004a; Bjorndal et al., 2000; Chaloupka and Balazs, 2005). The suggested density-dependent effect on growth in Akumal could be a consequence of the intraspecific resource competition for limited food, and probably space, supported by the population trend and foraging pasture conditions observed in the area. Numbers of nesting green turtles in the Mexican Caribbean Sea and 
the Gulf of Mexico have been increasing since 1990, suggesting a positive trend in population recovery in these areas (CONANP, 2011). An increase in sea turtle abundance has also been observed in Akumal since 2011 (this study) and persisted through 2015 (unpublished data). The dominant seagrass species T. testudinum had become less abundant in Akumal, and a total of 45 to $55 \%$ of the seagrass area has been grazed by sea turtles in the bay. Grazing plots have become less evident than ten years ago in response to sea turtle grazing behaviour, suggesting excessive browser pressure on seagrass beds, which results in overall low primary productivity, biomass and diversity (Molina and Van Tussenbroek, 2014). Estimations based on sea turtle abundance, food intake, seagrasses production and recovery time suggest that seagrass productivity has neared its carrying capacity to feed sea turtles in Akumal (Molina and Van Tussenbroek, 2014). Bjorndal et al. (2000) reported a lag of a year in the effect of growth rate related to the relative abundance of green turtles registered in the Bahamas that was not seen in our study. We suspect this is due to methods of calculation; Bjorndal used "calendar year" as the year at recapture, whereas we used year of first capture.

The monotonic size-specific growth function described by the GAM is characterised by faster growth rates during the developmental phase, with a declining growth rate as sexual maturity approaches (Balazs and Chaloupka, 2004a). Green turtles from Akumal displayed the maximum growth rates at size between 40 to $50 \mathrm{~cm}$ CCL with a steady decrease at a size $>60 \mathrm{~cm}$ CCL when turtles become closer to adult size. Mean size had a significant effect on growth of green turtles from Akumal as seen elsewhere in green (East Pacific, Gulf of California, Australia, Hawaii) (Balazs and Chaloupka, 2004a; Green, 1993; Limpus and Chaloupka, 1997; Seminoff et al., 2002b) and hawksbill sea turtles (Eretmochelys 
imbricata) (Chaloupka and Limpus, 1997). A linear negative effect of year on growth rates was found in this study. The significant effect of the calendar year on growth of green turtles offers information about interannual growth variability given environmental factors and account for the inherent time-dependent sampling desing (Balazs and Chaloupka, 2004a; Limpus and Chaloupka, 1997). In this study the inclusion of calendar year as a nominal covariate in an additional GAM allowed determining the parametric coefficients with significant effects and to identifying specific periods with the lowest growth rates (2008, 2009 and 2012). Considering the recapture interval as an explanatory variable in multivariate models allows accounting for potential bias given by the variability in sampling interval when working with mark-recapture data (Chaloupka and Limpus, 1997). In this work, the covariate recapture interval did not contribute in explaing the growth of green turtles from Akumal, conicinding with previous reports (Balazs and Chaloupka, 2004a; Bjorndal et al., 2000; Chaloupka and Limpus, 1997; Seminoff et al., 2002b).

The lower fit obtained in this work $\left(r^{2}<0.23\right.$, deviance explaining $\left.<33 \%\right)$ suggest that other factors may had influence on growth rates of green turtles from Akumal, such as, significant individual variability related to differences on age, sex, genetic and environmental factors (Caillouet et al., 1995; Chaloupka and Musick, 1997). Somatic growth is a time-dependent demographic process comprising age, cohort and year as confounded time effects (Chaloupka and Musick, 1997). Age of green turtles captured was unknown for the majority of the individuals ( $94 \%$ of sea turtles). In this study $13 \%(n=11)$ of the total growth increments considered came from head-started sea turtles (Zurita, 2015). Caution should be taken when growth rates are estimated from head-started sea turtles given the captivity condition; metabolic differences (e.g. higher thyroxine concentration) 
and fastest growth rates can occur during captivity (Limpus and Walter, 1980; Mendoca 1981; Moon et al., 1998) and it is possible that the size of head-started green turtle hatchlings were larger at time of release than wild green turtles of similar age (Caillouet et al., 1995). Genetic variability, which could also affect parameters measured here, was neither accounted. That said, the Caribbean feeding grounds (e.g. Akumal) are mixed stocks where individuals born in different, relatively close $(<3500 \mathrm{~km})$ nesting areas, congregate (Lahanas et al., 1998) and it would therefore be difficult to control for genetics, since effects of year (interannual variability) and cohort are confounding factors given the mixed longitudinal sampling design used with unknown age (Chaloupka and Musick, 1997).

Estimations, based in GAM predictions, about the amount of time a green turtle would require to spend in Akumal before reproducing (13-14 years) are the first approximations in this region about maturity, which coincided with those estimations for green turtles in the Bahamas (12-13 years) (Bjorndal et al., 2000) and with field observations in the Mexican Caribbean Sea. In Yucatan, sea turtles of known age, marked since hatchlings with tissue grafts and metallic tags, have been observed coming ashore to nest for the first time at an age between 11 and 16 years in Xcacel, Quintana Roo (CONANP, 2011). Our estimates assumed that sea turtles remained in the bay of Akumal without spending long periods in adjacent areas or migrating to Caribbean islands, where variation in environmental conditions resulting in differential biomass and primary production of seagrasses such as $T$. testudinum (Van Tussenbroek, 1995; Van Tussenbroek et al., 2014) could lead to varying growth rate estimates (Chaloupka et al., 2004). Even when interannual growth variability was accounted by the model, the frequency of stochastic events (e.g. hurricanes and tropical 
storms) that affect seagrass community, biomass and probably quality of food resources (Cruz-Palacios and Van Tussenbroek, 2005; Gallegos et al., 1992) may increase given climate change (Stenseth et al., 2002); thus, a major number of years may be required for sea turtles to spend in the feeding habitat of Akumal before they reach minimum nesting size and sexual maturity. The growth rate function of this study and the estimated number of years to grow before reproduce are constraint to the available data (size range $27-80 \mathrm{~cm}$ CCL, $n=86$ ), and conditioned to the explanatory variables used in this study. Increasing sample size, CUPE, frequency of recaptured individuals, and size range, would reduce individual and annual variability thus leading to better predictions. Results of this study are specific for Akumal feeding ground conditions and cannot be extrapolated to other sites in the region or outside the size range.

GAM is a nonparametric multivariate statistical model that have resulted to be an useful method to evaluate the non-linear relationship and effect of the combination of multiple covariates such as, recapture interval, year, sex, and mean size, to growth rates of green turtles around the globe (Balazs and Chaloupka, 2004a; Bjorndal et al., 2000; Chaloupka and Limpus, 1997; Limpus and Chaloupka, 1997; Seminoff et al., 2002b). Univariate statistics, such as the one used in this study to evaluate annual differences, can not account for the simultaneous effects of the environmental and intrinsec factors influencing growth, which could mislead conclusions (the significant annual differences in this study). Inclusion of data about seasonality (Labrada-Martagón et al. 2013), sea turtle abundance, biomass or type of food as explanatory variables may lead new information about growth patterns and density-dependent effects. 


\section{Conclusion}

A size-specific growth function for the green turtle (Ch. mydas) inhabiting in Mexican Caribbean is presented for the first time. Size-specific growth rates and the estimations derived from it are the first available demographic information about immature green turtles inhabiting in Akumal that could be used as a preliminary reference for future studies and monitoring programs. The monotonic size-specific growth function modelled presented the highest growth rate at about 40 and $50 \mathrm{~cm}$ CCL with a subsequent decrease as sea turtles approach to maturity. Mean size and calendar year were covariates that explained the growth rate of the green turtles; inclusion of calendar year as categorical covariate in GAM results very useful to understand annual variability in growth rates. The ecological relevance of Akumal bay as a foraging and developmental habitat for green turtles is confirmed in this study. Green turtles recruited to this habitat at a minimum size of $28 \mathrm{~cm}$ CCL, exhibited residency in the site for even 6 years and presented slow growth rates with annual variability. A density-dependent effect to growth is suggested by our data. An immature green turtle from Akumal would require more than 13 years to reach the mean nesting size and may reproduce. Demographic monitoring programs should continue in Akumal and be expanded to adjacent feeding grounds, in order to estimate specific growth rates along the geographic range distribution of this species in the region, and to be able in identifying changes related to sea turtle abundance, environmental factors or degradation of natural habitat conditions. 


\section{Acknowledgments}

The authors thank the Centro Ecológico Akumal for support in field work, especially P. Sánchez Navarro, A. Lorences Camargo, M. Calleros, S. Sarre, H. Lizárraga, M. Acévez; A. Orozco (Akumal Dive Center) and G. Arcila (Akumal Dive Shop) for their help providing boats for sampling; R. Castellanos Balam and S. Luna (El Colegio de la Frontera Sur) assisted with field work and database capture; K. A. Flores Cepeda and students from the Facultad de Agronomía y Veterinaria (UASLP) helped with sample collection. M. Monk (National Marine Fisheries Services, NOAA) for her invaluable help in coding GAM predictions. Comments and suggestions from T. M. Work (USGS National Wildlife Health Center) and C. Hernández-Camacho (CICIMAR-IPN) and by two anonymous reviewers help to improve the manuscript and the quality of the biological information presented. Funding for this project was provided in part by the Wildlife Conservation Society (Field Veterinary Program), the Wildlife Trust, the National Field and Wildlife Foundation, Flora Fauna y Cultura de México, A.C. All applicable international, national and/or institutional guidelines for the care and use of animals were followed. All samples were collected under permits from the Dirección General de Vida Silvestre, SEMARNAT (DGPA/DGVS/04631/12, DGPA/DGVS/05648/13, DGPA/DGVS/09454/14). This work was developed while VLM was a CONACYT postdoctoral fellow at the Programa de Doctorado en Ciencias Agropecuarias, Facultad de Agronomía y Veterinaria (UASLP). 


\section{References}

Balazs, G.H., 1995. Growth rates of immature green turtles in the Hawaiian Archipelago, in: Bjorndal, K.A. (Ed.), Biology and Conservation of sea turtles. Smithsonian Institution Press, Washington D.C., pp. 117-125.

Balazs, G.H., 1999. Factors to consider in the tagging of sea turtles, in: Eckert, K.L., Bjorndal, K.A., Abreu-Grobois, F.A., Donnelley, M. (Eds.), Research and Management techniques for the conservation of sea turtles. SSC/IUCN Marine Turtle Specialist Group, Pennsylvania, pp. 101-106.

Balazs, G.H., Chaloupka, M., 2004a. Spatial and temporal variability in somatic growth of green sea turtles (Chelonia mydas) resident in the Hawaiian Archipelago. Mar. Biol. 145, 1043-1059.

Balazs, G.H., Chaloupka, M., 2004b. Thirty-year recovery trend in the once depleted Hawaiian green sea turtle stock. Biol. Conserv. 117, 491-498.

Balazs, G.H., Chaloupka, M., 2006. Recovery trend over 32 years at the Hawaiian green turtle rookery of French Frigate Shoals. Atoll Res. Bull. 543, 147.

Ballorain, K., Ciccione, S., Bourjea, J., Grizel, H., Enstipp, M. and Georges, J.Y., 2010. Habitat use of a multispecific seagrass meadow by green turtles Chelonia mydas at Mayotte Island. Marine biology, 157(12), pp.2581-2590.

Barrera-Escorcia, G., Namihira-Santillán, P.E., 2004. Contaminación microbiológica en la zona costera de Akumal, Quintana Roo, México Microbiological contamination in the Akumal coastal zone, Quintana Roo State, Mexico. Hidrobiológica 14, 27-35.

Beverton, R.J.H., Holt, S.J., 1957. On the Dynamics of Exploited Fish Population. Chapman and Hall, London.

Bjorndal, K.A., 1999. Priorities for research in foraging habitats, in: Eckert, K.L., Bjorndal, K.A., Abreu-Grobois, F.A. (Eds.), Research and management techniques for the conservation of sea turtles. SSC/IUCN Marine Turtle Specialist Group, Pennsylvania, pp. 12-15.

Bjorndal, K.A., Bolten, A.B., 1988. Growth rates of immature green turtles, Chelonia mydas, on feeding grounds in the southern Bahamas. Copeia 555-564.

Bjorndal, K.A., Bolten, A.B., Chaloupka, M., 2000. Green turtle somatic growth model: evidence for density dependence. Ecol. Appl. 10, 269-282.

Bolten, A.B., 1999. Techniques for measuring sea turtles, in: Eckert, K.L., Bjorndal, K.A., AbreuGrobois, F.A., Donnelley, M. (Eds.), Research and Management techniques for the conservation of sea turtles. SSC/IUCN Marine Turtle Specialist Group, Pennsylvania, pp. 101-106.

Boulon, R.H., Frazer, N.B., 1990. Growth of wild juvenile Caribbean green turtles, Chelonia mydas. J. Herpetol. 24, 441-445.

Braun-McNeill, J., Epperly, S., Avens, L., Snover, M.L., Taylor, J.C., 2008. Growth rates of loggerhead sea turtles (Caretta caretta) from the western North Atlantic. Herpetol. Conserv. Bio. 3, 273-281.

Broderick, A.C., Coyne, M.S., Fuller, W.J., Glen, F., Godley, B.J., 2007. Fidelity and overwintering of sea turtles. P. Roy. Soc. B-Biol. Sci. 274, 1533-1539. 
Caillouet, C.W., Fontaine, C.T., Manzella-Tirpak, S.A., Williams, T.D. 1995. Growth of headstarted Kemp's ridley sea turtles (Lepidochelys kempii) following release, Chelonian Conserv. Bi. 1, 231-234.

Casale, P., Mazaris, A.D., Freggi, D., 2011. Estimation of age at maturity of loggerhead sea turtles Caretta caretta in the Mediterranean using length-frequency data. Endang. Species Res. 13, 123-129.

CEA, 2015. Programa Tortugas Marinas. Centro Ecológico Akumal.

CONANP, 2011. Programa de acción para la conservación de la especie: Torguga verde/negre Chelonia mydas, in: Marinas, C.T.d.P.N.p.l.C.d.1.T. (Ed.), PACE. SEMARNAT, Mexico, p. 53.

Congdon, J.D., Dunham, A.E., van Loben Sels, R.C., 1993. Delayed Sexual Maturity and Demographics of Blanding's Turtles (Emydoidea blandingii): Implications for Conservation and Management of Long-Lived Organisms. Conserv. Biol. 7, 826-833.

Cruz-Palacios, V., Van Tussenbroek, B.I., 2005. Simulation of hurricane-like disturbances on a Caribbean seagrass bed. J. Exp. Mar. Biol. Ecol. 324, 44-60.

Chaloupka, M., Balazs, G.H., 2005. Modelling the effect of fibropapilloma disease on the somatic growth dynamics of Hawaiian green sea turtles. Mar. Biol. 147, 1251-1260.

Chaloupka, M., Limpus, C.J., 1997. Robust statistical modelling of hawksbill sea turtle growth rates (southern Great Barrier Reef). Mar. Ecol. Porg. Ser. 146, 1-8.

Chaloupka, M., Limpus, C.J., Miller, J., 2004. Green turtle somatic growth dynamics in a spatially disjunct Great Barrier Reef metapopulation. Coral Reefs 23, 325-335.

Chaloupka, M.Y., Musick, J.A., 1997. Age, Growth, and Population Dynamics, in: Lutz, P.L., Musick, J.A. (Eds.), The biology of sea turtles, 12 ed. CRC, Boca Raton, p. 233.

Eberhardt, L.L., 1985. Assessing the dynamics of wild populations. J. Wildlife Manage. 9, 997-1012.

Gallegos, M.E., Merino, M., Marba, N., Duarte, C.M., 1992. Flowering of Thalassia testudinum banks ex König in the Mexican Caribbean: age-dependence and interannual variability. Aquat. Bot. 43, 249-255.

Godley, B.J., Richardson, S., Broderick, A.C., Coyne, M.S., Glen, F., Hays, G.C., 2002. Long-term satellite telemetry of the movements and habitat utilisation by green turtles in the Mediterranean. Ecography 25, 352-362.

Goldstein, H., 1968. Longitudinal studies and the measurement of change. The Statistician, 93-117.

Green, D., 1993. Growth rates of wild immature green turtles in the Galápagos Islands, Ecuador. J. Herpetol. 27, 338-341.

Haddon, M., 2001. Modelling and Quantitative Methods in Fisheries. Chapman and Hall/CRC, Boca Raton.

Hamann, M., Godfrey, M.H., Seminoff, J.A., Arthur, K., Barata, P.C.R., Bjorndal, K.A., Bolten, A.B., Broderick, A.C., Campbell, L.M., Carreras, C. 2010. Global research priorities for sea turtles: informing management and conservation in the 21st century. Endang. Species Res. 11, 245-269.

Hamann, M., Jessop, T.S., Limpus, C.J., Whittier, J.M., 2002a. Interactions among endocrinology, seasonal reproductive cycles and the nesting biology of the female green sea turtle. Mar. Biol. 823-830. 
Hamann, M., Limpus, C.J., Whittier, J.M., 2002b. Patterns of lipid storage and mobilisation in the female green sea turtle (Chelonia mydas). J. Comp. Physiol. B. 172, 485-493.

Hastie, T., Tibshirani, R., 1986. Generalized additive models. Statistical science, 297-310.

Heppell, S.S., Snover, M.L., Crowder, L., 2003. Sea Turtle Population Ecology, in: Lutz, P.L., Musick, J.A., Wyneken, J. (Eds.), The Biology of Sea Turtles, Vol II. CRC Press, Florida, pp. 275-306.

Katz, M.H., 2006. Multivariable Analysis. A Practical Guide for Clinicians. Cambridge University Press, Cambridge.

Koch, V., Brooks, L., Nichols, W.J., 2007. Population ecology of the green/black turtle (Chelonia mydas) in Bahía Magdalena, Mexico. Mar. Biol. 153, 35-46.

Koch, V., Nichols, W.J., Peckham, H., De la Toba, V., 2006. Estimates of sea turtle mortality from poaching and bycatch in Bahía Magdalena, Baja California Sur, Mexico. Bio. Conserv. 128, $327-334$.

Labrada-Martagón, V., Méndez, L., Gardner, S.C., Lopez-Castro, M.C., Zenteno-Savín, T., 2010. Health Indices of the green turtle (Chelonia mydas) along the Pacific coast of Baja California Sur, Mexico. I. Blood biochemistry values. Chelonian Conserv. Bi. 9, 162-172.

Labrada-Martagón, V., Tenorio, P.A., Méndez, L., Zenteno-Savín, T., 2011. Oxidative stress indicators and chemical contaminants in East Pacific green turtles (Chelonia mydas) inhabiting two foraging coastal lagoons in the Baja California peninsula. Comp. Biochem. Phys. C. 154, $65-75$.

Labrada-Martagón, V., Méndez, L., Mangel, M., Zenteno-Savín, T., 2013. Applying generalized linear models as an explanatory tool of sex steroids, thyroid hormones and their relationships with environmental and physiologic factors in immature East Pacific green sea turtles (Chelonia mydas). Comp. Biochem. Phys. A.166, 91-100.

Labrada-Martagón, V., Zenteno-Savín, T., Mangel, M., 2014. Linking physiological approaches to marine vertebrate conservation: using sex steroid hormone determinations in demographic assessments. Con. Phys. 2, cot035.

Lahanas, P.N., Bjorndal, K.A., Bolten, A.B., Encalada, S.E., Miyamoto, M.M., Valverde, R.A., Bowen, B.W., 1998. Genetic composition of a green turtle (Chelonia mydas) feeding ground population: evidence for multiple origins. Mar. Biol. 130, 345-352.

Limpus, C.J., 1992. Estimation of tag loss in marine turtle research. Wildlife Res. 19, 457-469.

Limpus, C.J., Chaloupka, M., 1997. Nonparametric regression modelling of green sea turtle growth rates (southern Great Barrier Reef). Mar. Ecol. Prog. Ser. 149, 23-34.

Limpus, C.J., Walter, D.G., 1980. The growth of immature green turtles (Chelonia mydas) under natural conditions. Herpetologica 36, 162-165.

Lopez-Castro, M.C., Koch, V., Mariscal-Loza, A., Nichols, W.J., 2010. Long term monitoring of black turtles Chelonia mydas at coastal foraging areas off the Baja California Peninsula. Endang. Species Res. 11, 35-45.

Lopez-Mendilaharsu, M., Gardner, S.C., Seminoff, J.A., Riosmena, R., 2005. Identifying critical foraging habitats of the green turtle (Chelonia mydas) along the Pacific coast of the Baja California peninsula, Mexico. Aquat. Conserv. 15, 259-269. 
Makowski, C., Seminoff, J.A., Salmon, M., 2006. Home range and habitat use of juvenile Atlantic green turtles (Chelonia mydas L.) on shallow reef habitats in Palm Beach, Florida, USA. Mar. Biol. 148, 1167-1179.

Maldonado, M.A., Lorences-Camargo, A., Sánchez-Navarro, P., 2006. Estudio técnico justificativo para el establecimiento del área de refugio para la protección de tortugas marinas de la bahías de Akumal, in: SILVESTRE, S.D.G.P.L.P.A.D.G.D.V. (Ed.). SEMARNAT, Mexico, p. 45.

Mancini, A., Koch, V., 2009. Sea turtle consumption and black market trade in Baja California Sur, Mexico. Endang. Species Res. 7, 1-10.

Marquez, R., 1990. Sea turtles of the world. Species catalogue. Food and Agriculture Organization, Rome.

McCullagh, P., Nelder, J.A., 1989. Generalized Linear Models, Generalized Linear Models, 2nd Second ed. Chapman and Hall, CRC, London, p. 511.

Méndez, D., Cuevas, E., Navarro, J., González-Garza, B.I., Guzmán-Hernández, V., 2013. Rastreo satelital de las hembras de tortuga blanca Chelonia mydas y evaluación de sus ámbitos hogareños en la costa norte de la península de Yucatán, México. Rev. Biol. Mar. Oceanog. 48, 497-509.

Mendonça, M.T. 1981. Comparative growth rates of wild immature Chelonia mydas and Caretta caretta in Florida. J. Herpetol. 15(4): 444-447.

Mendonça, M.T., Ehrhart, L.M., 1982. Activity, population size and structure of immature Chelonia mydas and Caretta caretta in Mosquito Lagoon, Florida. Copeia 161-167.

Molina, A.L., Van Tussenbroek, B.I., 2014. Patch dynamics and species shifts in seagrass communities under moderate and high grazing pressure by green sea turtles. MEPS 517, $143-157$.

Moon, D., MacKenzie, D.S., Owens, D.W., 1998. Serum thyroid hormone levels in wild and captive sea turtles. Korean J. Biol. Sci. 2, 177-181.

Peckham, S.H., Maldonado-Diaz, D., Koch, V., Mancini, A., Gaos, A., Tinker, M.T., Nichols, W.J., 2008. High mortality of loggerhead turtles due to bycatch, human consumption and strandings at Baja California Sur, Mexico, 2003 to 2007. Endang. Species Res. 5, 171-183.

Pritchard, P.C.H., 1997. Evolution, Phylogeny and current status, in: Lutz, P.L., Musick, J.A. (Eds.), The biology of sea turtles. CRC Press, Boca Raton, pp. 1-28.

R Core Team, 2016. R: A language and environment for statistical computing. R Foundation for Statistical Computing, Vienna, Austria.

Ruiz-Alonso, M., 2008. Biología de Chelonia mydas en Akumal, México, Biodiversidad y Conservación Animal, Valencia, p. 63.

Schmidt, J.V., 1916. Marking experiments with turtles in the Danish West Indies. Meddelelser fra Kommissionen for Havundersogelser Serie Fiskerei 5, 1-26.

Seminoff, J.A., Resendiz, A., Nichols, W.J., 2002a. Home range of green turtles Chelonia mydas at a coastal foraging area in the Gulf of California, Mexico. Mar. Ecol. Prog. Ser. 242, 253-265.

Seminoff, J.A., Resendiz, A., Nichols, W.J., Jones, T.T., 2002b. Growth rates of wild green turtles Chelonia mydas at a temperate foraging area in the Gulf of California, Mexico. Copeia 3, 610-617.

Slater, K., 2014. CEA/Operation Wallacea Immature green turtle monitoring report 2014 CEA/Operation Wallacea, Lincolnshire, p. 19. 
StatSoft, I., 2007. STATISTICA (data analysis software system), version 8.0.

Stearns, S.C., 1992. The evolution of life histories. Oxford University Press, Oxford.

Stenseth, N.C., Mysterud, A., Ottersen, G., Hurrell, J.W., Chan, K.S., Lima, M., 2002. Ecological effects of climate fluctuations. Science,297, 1292-1296.

Thomassiny, J.S., Chan, E., 2011. Cambios en el uso de suelo., in: Pozo, C., Armijo, N., Calmé, S. (Eds.), Riqueza Biológica de Quintana Roo. Un Análisis para su Conservación. Comisión Nacional para el Conocimiento y Uso de la Biodiversidad (CONABIO). Quintana Roo, pp. 132-135.

Van Tussenbroek, B.I., 1995. Thalassia testudinum leaf dynamics in a Mexican Caribbean coral reef lagoon. Mar. Biol. 122, 33-40.

Van Tussenbroek, B.I., Cortés, J., Collin, R., Fonseca, A.C., Gayle, P.M.H., Guzmán, H.M., Jácome, G.E., Juman, R., Koltes, K.H., Oxenford, H.A., 2014. Caribbean-Wide, Long-Term Study of Seagrass Beds Reveals Local Variations, Shifts in Community Structure and Occasional Collapse. Plos One 9, 1-13.

Velez-Zuazo, X., Quiñones, J., Pacheco, A.S., Klinge, L., Paredes, E., Quispe, S., Kelez, S., 2014. Fast growing, healthy and resident green turtles (Chelonia mydas) at two neritic sites in the central and northern coast of Peru: implications for conservation. Plos One 9, 1-12.

Wallace, B.P., Kilham, S.S., Paladino, F.V., Spotila, J.R., 2006a. Energy budget calculations indicate resource limitation in Eastern Pacific leatherback turtles. Mar. Ecol. Prog. Ser. 318, 263-270.

Wallace, B.P., Seminoff, J.A., Kilham, S.S., Spotila, J.R., Dutton, P., 2006b. Leatherback turtles as oceanographic indicators: stable isotope analyses reveal a trophic dichotomy between ocean basins. Mar. Biol. 149, 953-960.

Williams, S.L., 1988. Thalassia testudinum productivity and grazing by green turtles in a highly disturbed seagrass bed. Mar. Biol. 98, 447-455.

Wood, S., 2006. Generalized additive models: an introduction with R. CRC press.

Wood, S., 2016. Package "mgcv". R package version, pp. 1-256.

Zurita, J.C., 2015. Biología y conservación de las tortugas marinas de Quintana Roo, Facultad de Ciencias. UNAM, D.F., p. 237.

Zurita, J.C., Herrera, R., Prezas, B., 1993. Tortugas Marinas del Caribe., in: Salazar Vallejo, S.I., González, N.E. (Eds.), Biodiversidad Marina y Costera de México. CONABIO/CIQRO, Chetumal, pp. 735-751.

Zuur, A.F., Ieno, E.N., Walker, N.J., Saveliev, A.A., Smith, G.M., 2009. Mixed effects models and extensions in ecology with R. Springer, New York. 
Table 1. Annual capture per unit effort (CPUE) and number of green turtles (Chelonia mydas) captured and recaptured in Akumal, Quintana Roo, during 2004-2014.

\begin{tabular}{cccccc} 
Year & \multicolumn{2}{c}{$\begin{array}{c}\text { Number of } \\
\text { green turtles }\end{array}$} & & & \\
\cline { 2 - 4 } & Capture & Recapture & $\begin{array}{c}\text { Recapture } \\
(\%)\end{array}$ & $\begin{array}{c}\text { Total unit } \\
\text { effort (hours) }\end{array}$ & $\begin{array}{c}\text { Annual } \\
\text { CPUE }\end{array}$ \\
\hline 2004 & 14 & 5 & 35.7 & 10.5 & 1.33 \\
2005 & 0 & - & - & 0 & - \\
2006 & 21 & 18 & 85.7 & 13.95 & 1.51 \\
2007 & 4 & 1 & 25 & 5.5 & 0.73 \\
2008 & 21 & 6 & 28.6 & 9.08 & 2.31 \\
2009 & 14 & 4 & 28.6 & 6.41 & 2.18 \\
2010 & 7 & 4 & 57.1 & 4 & 1.75 \\
2011 & 8 & 6 & 75 & 5.4 & 1.48 \\
2012 & 20 & 13 & 65 & 8 & 2.50 \\
2013 & 33 & 13 & 39.4 & 13 & 2.54 \\
2014 & 24 & 6 & 25 & 9.32 & 2.58 \\
\hline Total & 166 & 76 & & & \\
\hline
\end{tabular}


Table 2. Growth rates of green turtles (Chelonia mydas) from Akumal, Quintana Roo, grouped by year of capture (2004-2014).

\begin{tabular}{|c|c|c|c|c|c|c|c|c|c|}
\hline \multirow[b]{2}{*}{ Year } & \multicolumn{2}{|c|}{ Number of green turtles } & \multicolumn{3}{|c|}{ Recapture interval (months) } & \multicolumn{2}{|c|}{ Growth rate $\left(\mathrm{cm} \mathrm{CCL} \mathrm{yr}^{-1}\right)$} & \multirow[b]{2}{*}{$\begin{array}{l}\text { Mean size range }{ }^{\mathrm{a}} \\
(\mathrm{CCL}, \mathrm{cm})\end{array}$} & \multirow[b]{2}{*}{$n$} \\
\hline & $\begin{array}{c}\text { First } \\
\text { capture }\end{array}$ & $\begin{array}{c}\text { Recapture } \\
\text { (>11 months) }\end{array}$ & Mean & Median & Range & Mean $\pm 95 \%$ CI & Range & & \\
\hline 2004 & 14 & 5 & 27.5 & 28 & $11-49$ & $5.88 \pm 1.75$ & $3.91-9.36$ & $55.85-69$ & 8 \\
\hline 2005 & 0 & - & - & - & - & - & - & - & 0 \\
\hline 2006 & 21 & 13 & 20.45 & 17 & $11-49$ & $6.84 \pm 1.17$ & $2.87-14.03$ & $34.5-70.5$ & 22 \\
\hline 2007 & 4 & 1 & 16.50 & 16.5 & $16-17$ & $8.48 \pm 17.12$ & $7.13-9.83$ & $57.85-64.4$ & 2 \\
\hline 2008 & 21 & 5 & 15.64 & 13 & $11-28$ & $4.86 \pm 1.90$ & $0.38-9.42$ & $37.6-77.8$ & 11 \\
\hline 2009 & 14 & 3 & 21.17 & 16 & $11-41$ & $3.48 \pm 6.64$ & $-8.05-9.84$ & $51.15-67.6$ & 6 \\
\hline 2010 & 7 & 4 & 17.25 & 14 & $11-29$ & $5.70 \pm 1.90$ & $2.73-9.50$ & $55.75-67.5$ & 8 \\
\hline 2011 & 8 & 5 & 14.56 & 12 & $11-25$ & $5.56 \pm 1.15$ & $3.38-8.03$ & $54.15-65.55$ & 9 \\
\hline 2012 & 20 & 11 & 16.57 & 16 & $12-28$ & $4.02 \pm 1.44$ & $-3.6-6.94$ & $47.9-78.05$ & 14 \\
\hline 2013 & 33 & 6 & 13.67 & 13 & $11-20$ & $4.65 \pm 1.57$ & $2.40-6.43$ & $55.65-80.7$ & 6 \\
\hline 2014 & 24 & 0 & - & - & - & - & - & - & 0 \\
\hline Total & 166 & & & & & & & & 86 \\
\hline $\begin{array}{l}\text { Absolute } \\
\text { resident g }\end{array}$ & $\begin{array}{l}\operatorname{th}^{\mathrm{b}}(\mathrm{cm} \mathrm{C} \\
\text { turtles }(>\end{array}$ & $\begin{array}{l}\left.\mathrm{L} \mathrm{yr}^{-1}\right) \text { of } \\
4 \text { months) }\end{array}$ & 40.56 & 36 & $24-79$ & $5.83 \pm 0.61$ & $1.25-10$ & $45.60-71.25$ & 32 \\
\hline
\end{tabular}

$\mathrm{CCL}$, curve carapace length; $\mathrm{CI}, 95 \%$ confidence interval, ${ }^{\mathrm{a}}$, mean size range denotes the arithmetic mean of size at first capture and size at recapture; $n$, number of recaptures; ${ }^{\text {b }}$, absolute growth (showed in the last row) was calculated in sea turtles with recapture intervals $>24$ months as follows $\left(\mathrm{CCL}_{\text {last recapture }}-\mathrm{CCL}_{\text {first }}\right.$ capture/years). 
Table 3. Relative frequency of recapture data and growth rates of green turtles (Chelonia mydas) from Akumal, Quintana Roo, grouped by mean size interval.

\begin{tabular}{|c|c|c|c|}
\hline \multirow{2}{*}{$\begin{array}{c}\text { Size interval } \\
\left(\text { Mean }^{\mathrm{a}} \text { CCL cm }\right)\end{array}$} & \multirow[b]{2}{*}{ Relative frequency } & \multirow{2}{*}{$\begin{array}{c}\text { Growth rate }\left(\mathrm{cm} \mathrm{CCL} \mathrm{yr}^{-1}\right) \\
\text { Mean } \pm 95 \% \text { CI }\end{array}$} & \multirow[b]{2}{*}{$n$} \\
\hline & & & \\
\hline $34-40.5$ & 0.03 & $5.31 \pm 8.96$ & 3 \\
\hline $40.6-47.1$ & 0.07 & $6.39 \pm 3.16$ & 6 \\
\hline $47.2-53.7$ & 0.09 & $7.50 \pm 1.65$ & 8 \\
\hline $53.8-60.3$ & 0.31 & $6.03 \pm 0.86$ & 27 \\
\hline $60.4-66.9$ & 0.33 & $5.20 \pm 0.64$ & 28 \\
\hline $67-73.5$ & 0.13 & $3.19 \pm 3.78$ & 11 \\
\hline $73.6-80.1$ & 0.02 & $3.67 \pm 17.26$ & 2 \\
\hline $80.2-86.7$ & 0.01 & 3.71 & 1 \\
\hline $\begin{array}{c}\text { Total number of recaptures } \\
\text { (recapture interval >11 months) }\end{array}$ & 86 & & \\
\hline
\end{tabular}

CCL, curve carapace length; ${ }^{a}$, mean CCL denotes the arithmetic mean of size at first capture and size at recapture; $95 \% \mathrm{CI}$, confidence interval; $n$, number of individuals 
Table 4. Summary of generalized additive model (GAM) fitted to growth rate (cm curve carapace length $\left.\mathrm{yr}^{-1}\right)$ of immature green turtles $($ Chelonia mydas) from Akumal ( $n=86)$.

\begin{tabular}{|c|c|c|c|c|c|c|c|c|c|c|c|c|c|c|}
\hline \multirow[t]{2}{*}{ Model } & \multirow[t]{2}{*}{ Covariate } & \multicolumn{4}{|c|}{ Parametric coefficients } & \multicolumn{7}{|c|}{ Nonparametric effects } & \multicolumn{2}{|c|}{ ANOVA } \\
\hline & & Estimate & $\begin{array}{c}\text { Std. } \\
\text { Error }\end{array}$ & $\mathbf{t}$ & $\mathbf{p}$ & edf & Ref.df & $\mathbf{F}$ & $\mathbf{p}$ & $\mathbf{R}^{2}$ & $\begin{array}{r}\text { Deviance } \\
\text { explained }\end{array}$ & AIC & $\begin{array}{l}\text { Res. Dev. } \\
\text { difference }\end{array}$ & $\mathbf{p}$ \\
\hline \multirow{4}{*}{$\begin{array}{l}\text { Growth } \sim \text { Mean Size }+ \\
\text { Recapture interval }+ \\
\text { Year }\end{array}$} & Intercept & 5.45 & 0.28 & 19.19 & $<0.001$ & & & & & 0.19 & $22.9 \%$ & 421.6 & 1 & - \\
\hline & Mean size & & & & & 1.78 & 2.30 & 3.48 & 0.03 & & & & & \\
\hline & Recapture & & & & & 0.86 & 1.13 & 3.04 & 0.08 & & & & & \\
\hline & Year & & & & & 1.18 & 1.56 & 3.32 & 0.05 & & & & & \\
\hline \multirow{11}{*}{$\begin{array}{l}\text { Growth } \sim \text { Mean size }+ \\
\text { Recapture interval }+ \\
\text { factor (year) }\end{array}$} & Intercept & 6.66 & 0.96 & 6.93 & $<0.001$ & & & & & 0.23 & $32.5 \%$ & 423 & -69.80 & 0.16 \\
\hline & 2006 & 0.006 & 1.11 & 0.006 & 0.99 & & & & & & & & & \\
\hline & 2007 & 1.77 & 2.06 & 0.86 & 0.39 & & & & & & & & & \\
\hline & 2008 & -2.45 & 1.32 & -1.86 & 0.06 & & & & & & & & & \\
\hline & 2009 & -3.17 & 1.41 & -2.23 & $0.02 *$ & & & & & & & & & \\
\hline & 2010 & -0.79 & 1.32 & -0.58 & 0.55 & & & & & & & & & \\
\hline & 2011 & -1.36 & 1.31 & -1.01 & 0.30 & & & & & & & & & \\
\hline & 2012 & -2.45 & 1.19 & -2.02 & $0.04 *$ & & & & & & & & & \\
\hline & 2013 & -1.45 & 1.47 & -0.96 & 0.32 & & & & & & & & & \\
\hline & Mean size & & & & & 1.85 & 2.39 & 3.88 & 0.01 & & & & & \\
\hline & $\begin{array}{c}\text { Recapture } \\
\text { interval }\end{array}$ & & & & & 0.81 & 1.10 & 2.68 & 0.10 & & & & & \\
\hline
\end{tabular}

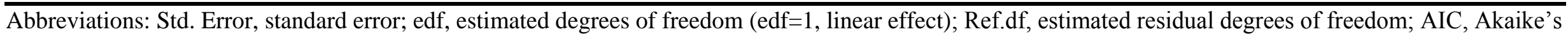
Information Criterion; Res. Dev. difference, Residual Deviance difference. Mean size=curve carapace length; *, significant parametric coefficients. 


\section{Figure captions}

Fig. 1 Size class distribution of green turtle (Chelonia mydas) population in Akumal, Quintana Roo. Vertical line represents mean nesting size of females from Quintana Roo according to Zurita et al. (1993).

Fig. 2 a) Recapture frequency for green turtles (Chelonia mydas) in Akumal, Quintana Roo, grouped by recapture interval (range, 1-49 months); b) Maximum number of years that green turtles (Chelonia mydas) remained in Akumal, Quintana Roo, during 2004-2014.

Fig. 3 a) Relationship between mean growth rate ( $\mathrm{cm} \mathrm{CCL} \mathrm{yr}^{-1}$ ) and relative green turtle abundance (sea turtles $\mathrm{h}^{-1}$ ); dotted lines represent the $95 \%$ confidence bands; b) Mean

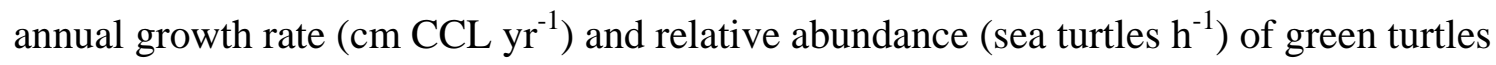
(Chelonia mydas) from Akumal, Quintana Roo, plotted by year of capture. * denotes years with statistical significance according to GAM analysis summarized in Table 4.

Fig. 4 Estimated smoothing curves for the GAM model fitted to growth rates (cm CCL yr ${ }^{-1}$ ) of green sea turtles (Chelonia mydas) from Akumal, Quintana Roo. The response variable "growth rate" is presented in $y$-axis as a centred smoother function scale. The solid line is the cubic smoothing spline and grey shadow $95 \%$ confidence bands. Vertical lines along $x$ axis indicate values of covariates.

Fig. 5 a) Size-specific growth rate function derived from a GAM comprising the covariates mean size (cm CCL), recapture interval (months) and year; growth rates (cm CCL yr ${ }^{-1}$ ) are presented on original scale in $y$-axis. b) Size-specific estimations about number of years to grow before reaching mean nesting size (106.6 cm CCL, Zurita et al., 1993) based on 
growth rate predictions of GAM; estimations showed was obtained by holding constant covariates year (2009) and mean recapture interval (18.4 months). 


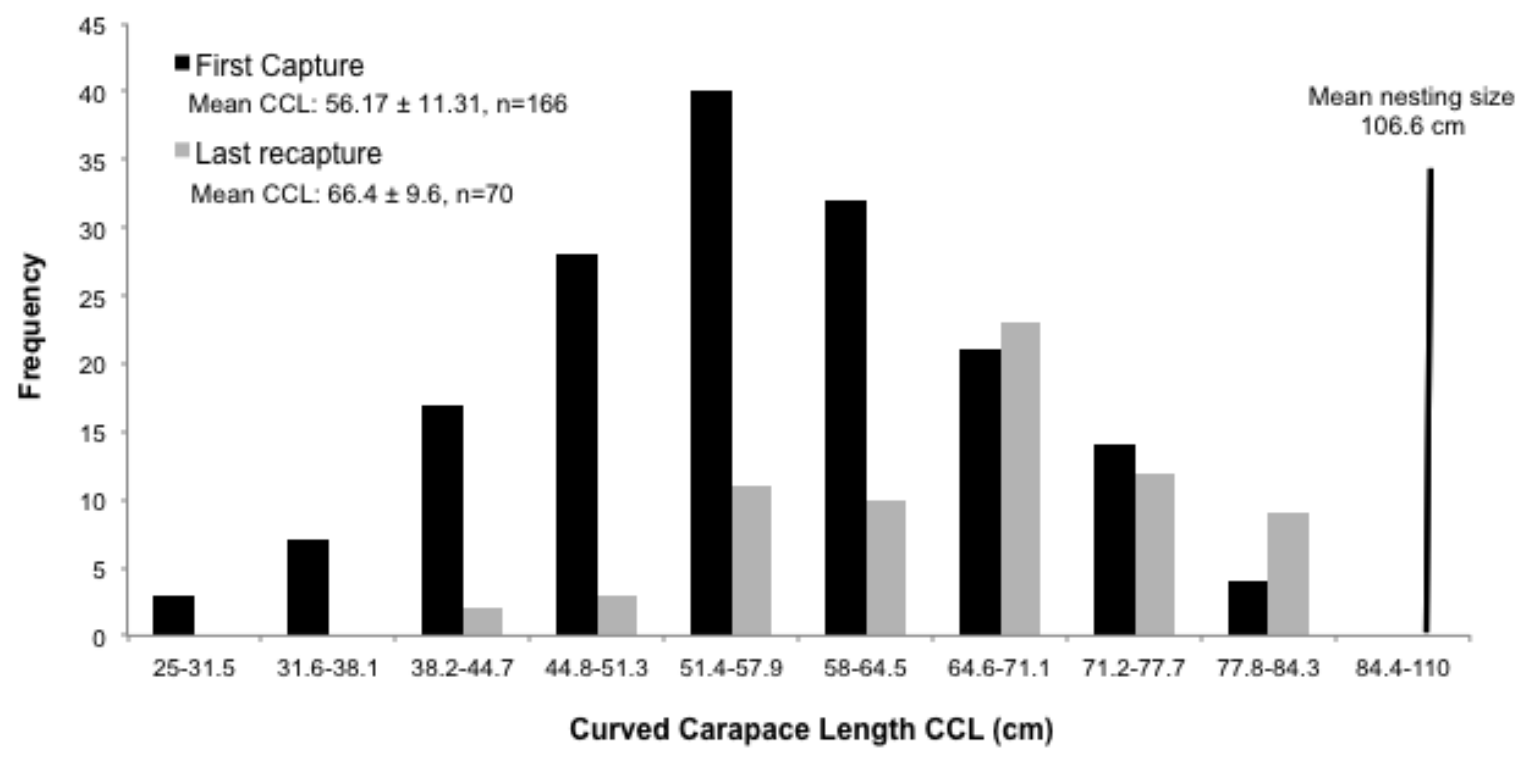

Figure 1. 


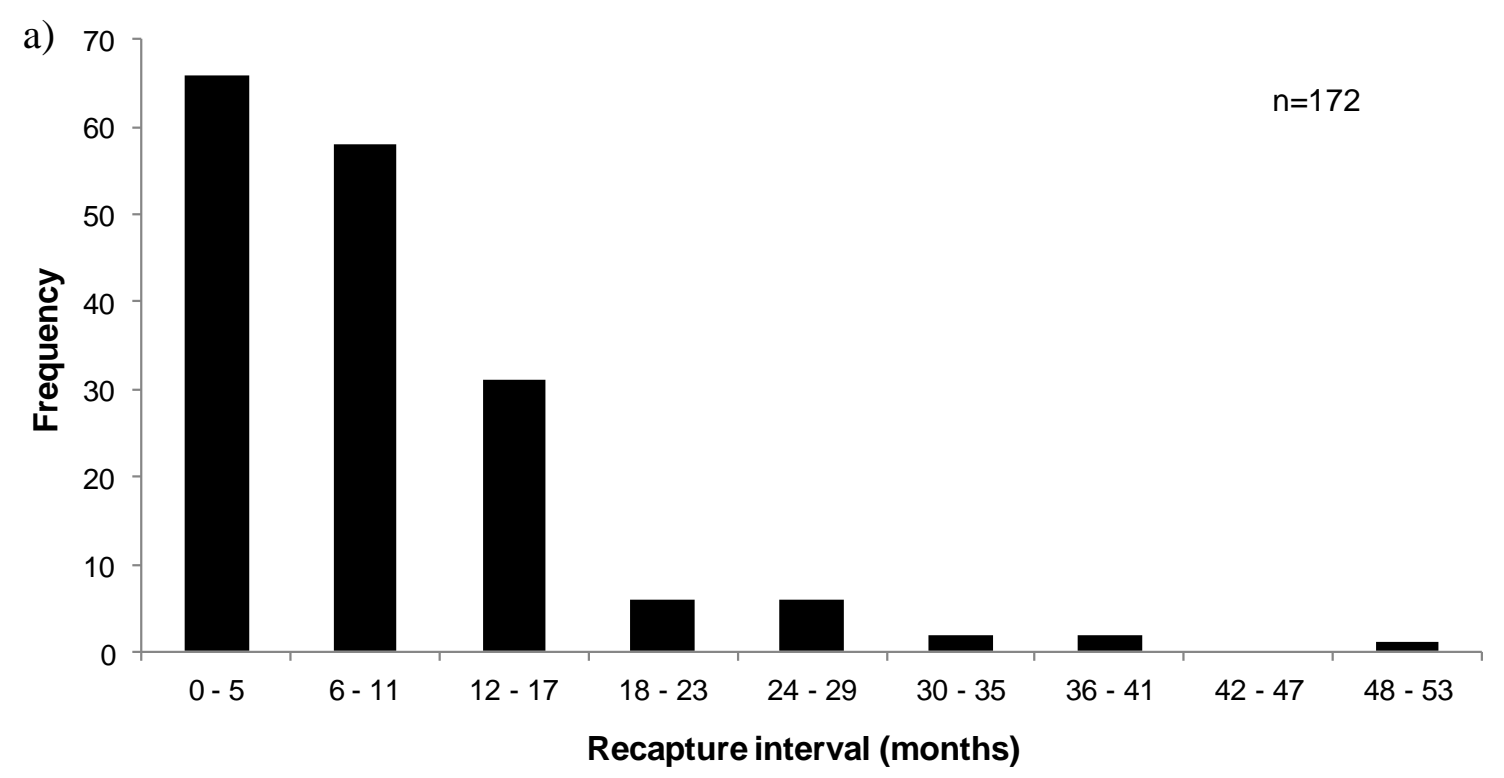

b)

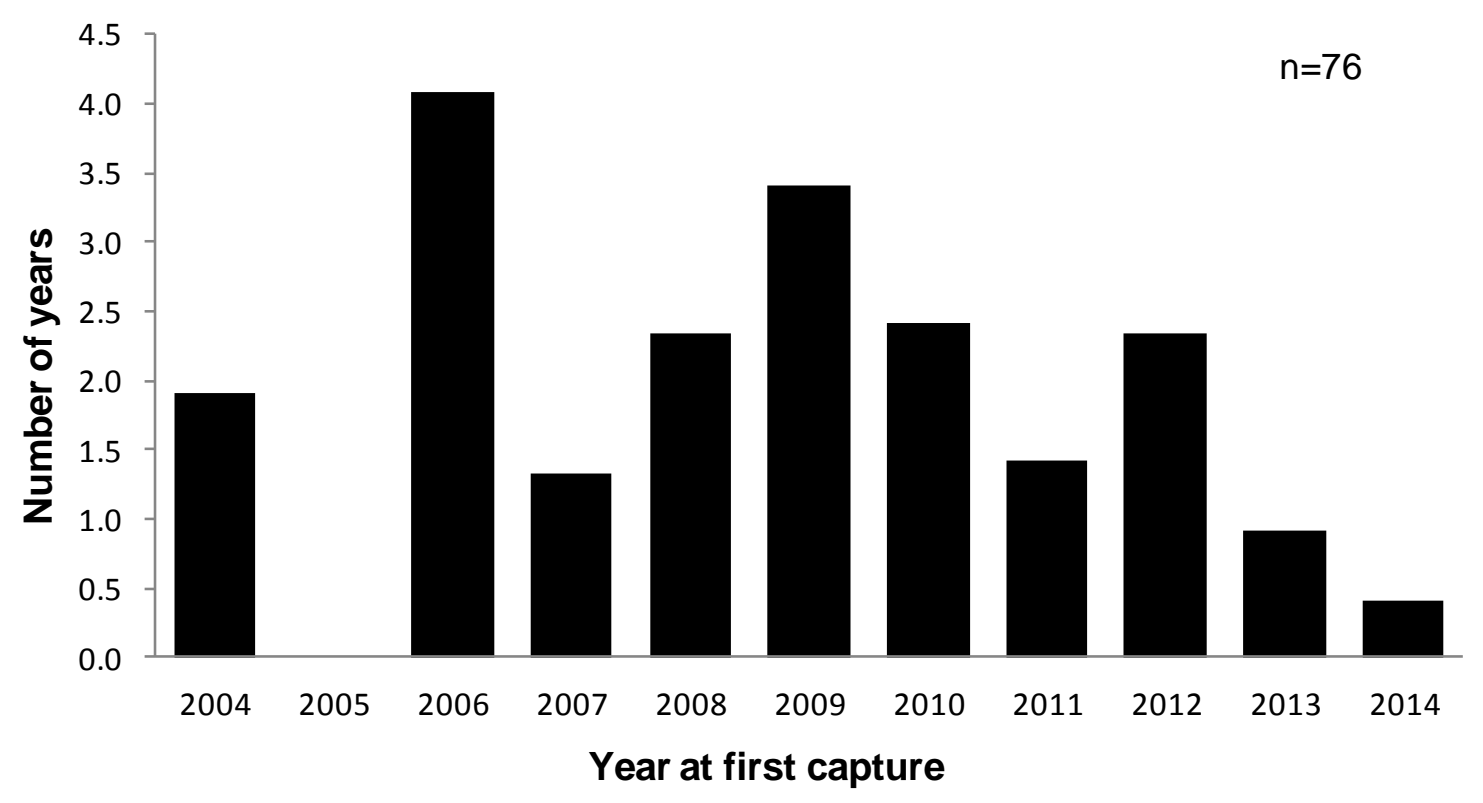

Figure 2. 
a)

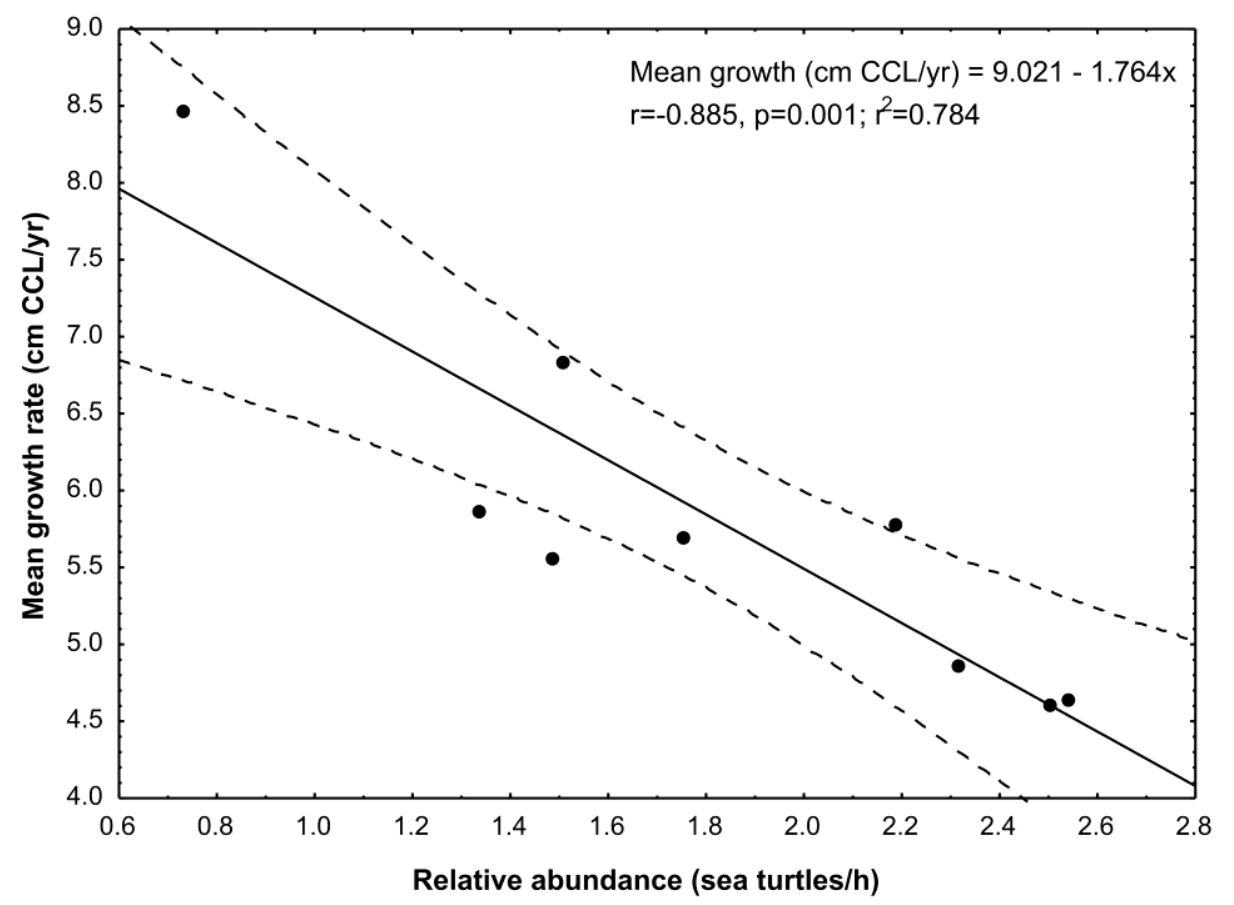

b)

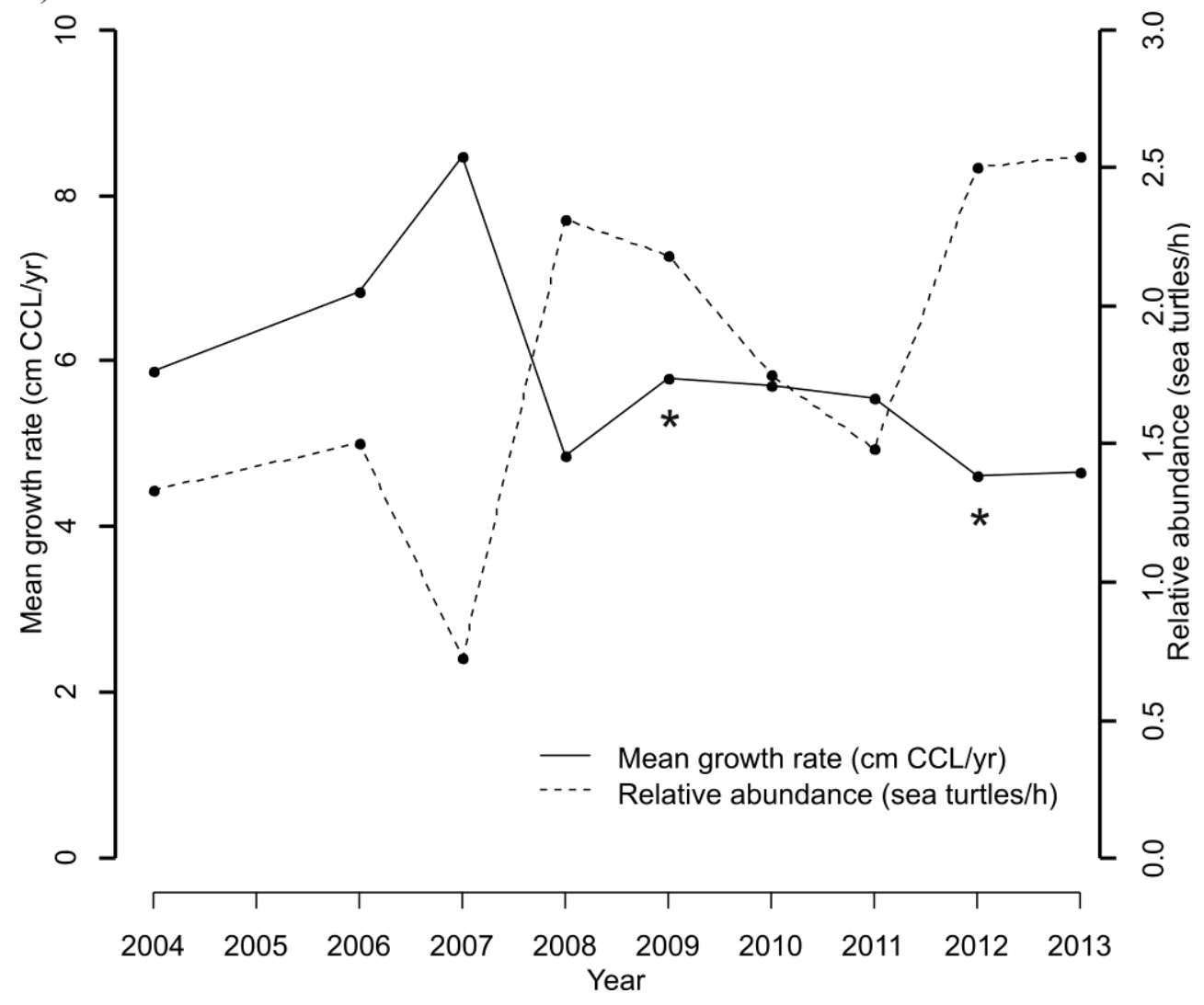

Figure 3. 
$r^{2}=0.19$, deviance explained $=22.7 \%, n=86$
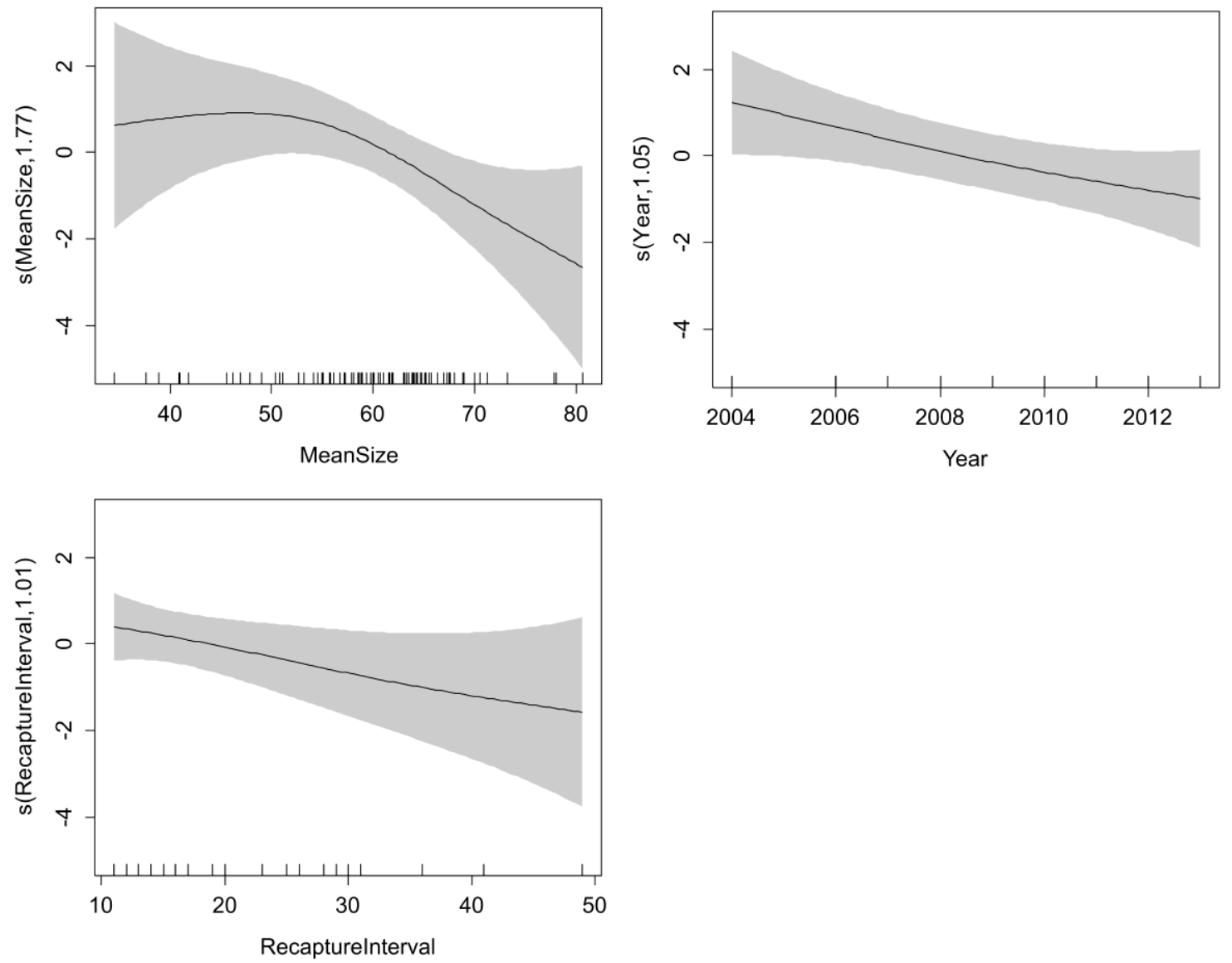

Figure 4. 
a)

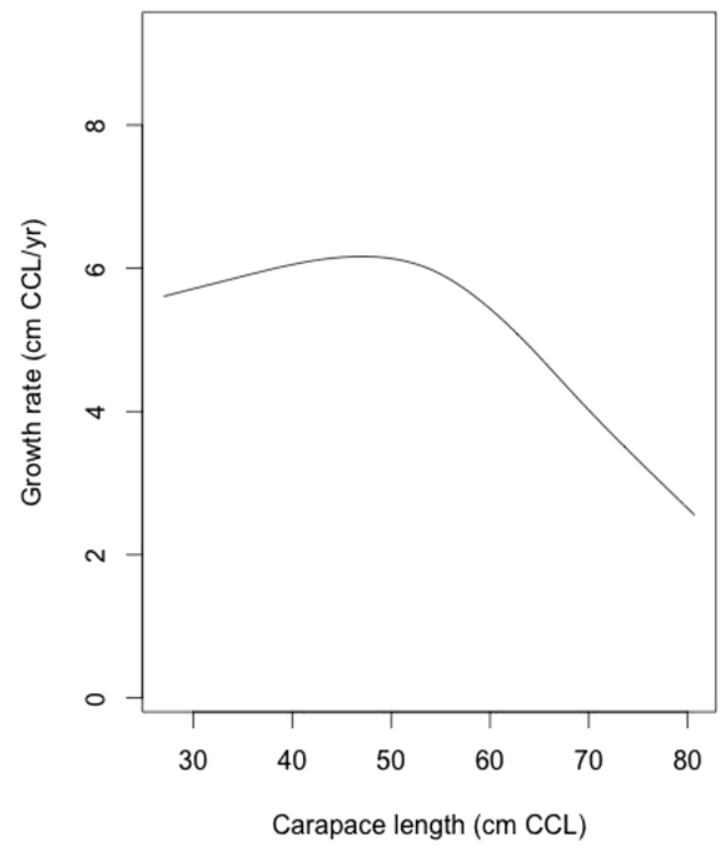

b)

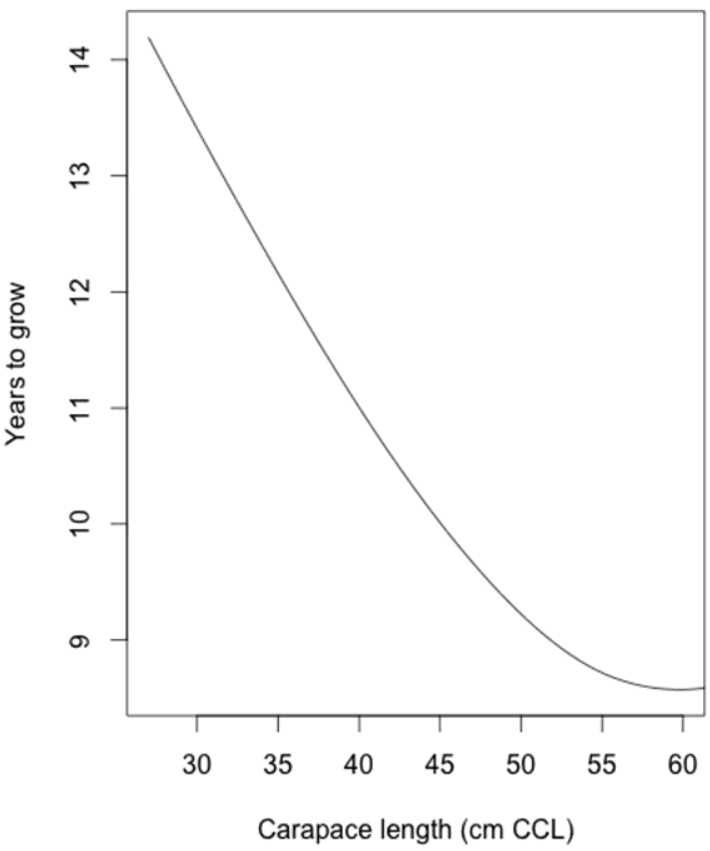

Figure 5. 